\title{
Antibacterial activity of Centaurea pumilio L. root and aerial part extracts against some multidrug resistant bacteria
}

Huda Naeim 1,2,3, Amr El-Hawiet ${ }^{4}$, Raoufa A. Abdel Rahman², Ahmed Hussein', Maha A. El Demellawy ${ }^{3}$ and Amira M. Embaby ${ }^{1 *}$ (D)

\begin{abstract}
Background: In the context of searching for potent, safe, natural antimicrobial agents to combate the global antimicrobial resistance (AMR) phenomenon, the current study evaluates for the first time ever, the broad-spectrum antimicrobial activity of essential oil (EO) and extracts from the rare wild plant Centaurea pumilio L.. It has tremendous ethnomedicinal values; its dried root is used as a fattening agent, a treatment for bad breath and diabetes, and screened for schistosomicidal activity.

Methods: C. pumilio EO was extracted by hydrodistillation using a Clevenger apparatus. Chemical constituents of aerial part were extracted using a sequential solvent/solvent procedure employing four solvents with increasing polarities in the following order: petroleum ether, chloroform, ethyl acetate, and n-butanol. The chemical constituents were identified by GC-MS. Fifty-two microbial strains were used; twenty-six multidrug resistant (MDR), sixteen clinical, and ten reference strains. The identification of the microbial strains was performed by MALDI-TOFMS. The antimicrobial activity of the EO and the aerial part and the root extracts was assessed through disc diffusion assay. A minimum inhibitory concentration (MIC) of the EO and extracts was determined using the broth micro-dilution method.

Results: The growth of reference and clinical strains was inhibited by EO, methanol, chloroform, and ethyl acetate aerial part extracts and chloroform root extract. The MDR strains growth, however, was inhibited only by EO and chloroform aerial part extract. GC-MS identified for the first time eighteen constituents from aerial part EO and chloroform extract each. EO showed antimicrobial activity against the reference, clinical, and MDR strains with MIC values of $31.25-125,31.25-125$, and $62.50-250 \mu \mathrm{g} / \mathrm{mL}$, respectively. Methanol aerial part extract exhibited high antimicrobial activities with MIC values of $62.50-250 \mu \mathrm{g} / \mathrm{mL}$ against reference and clinical strains. Chloroform root extract displayed strong antimicrobial activity against reference and clinical strains recording MIC values of 62.50$250 \mu \mathrm{g} / \mathrm{mL}$ and $62.50-125 \mu \mathrm{g} / \mathrm{mL}$, respectively. The chloroform aerial part extract demonstrated potent antimicrobial activity against the reference, clinical, and MDR strains with $31.25,31.25$, and $15.62 \mu \mathrm{g} / \mathrm{mL}$ MIC values, respectively.

\footnotetext{
* Correspondence: amira.embaby@alexu.edu.eg

'Department of Biotechnology, Institute of Graduate Studies and Research,

Alexandria University, 163 Horreya Avenue, Chatbye, P.O.Box 832, Alexandria, Egypt

Full list of author information is available at the end of the article
}

C C The Author(s). 2020 Open Access This article is licensed under a Creative Commons Attribution 4.0 International License, which permits use, sharing, adaptation, distribution and reproduction in any medium or format, as long as you give appropriate credit to the original author(s) and the source, provide a link to the Creative Commons licence, and indicate if changes were made. The images or other third party material in this article are included in the article's Creative Commons licence, unless indicated otherwise in a credit line to the material. If material is not included in the article's Creative Commons licence and your intended use is not permitted by statutory regulation or exceeds the permitted use, you will need to obtain permission directly from the copyright holder. To view a copy of this licence, visit http://creativecommons.org/licenses/by/4.0/. The Creative Commons Public Domain Dedication waiver (http://creativecommons.org/publicdomain/zero/1.0/) applies to the data made available in this article, unless otherwise stated in a credit line to the data. 
(Continued from previous page)

Conclusions: Present data unravel the C. pumilio pharmacological magnitude to discover eco-friendly potent antimicrobial agents to fight AMR phenomenon.

Keywords: AMR, Centaurea pumilio L., Aerial part, Root, Essential oil, Plant extracts, Antimicrobial activity, MDR strains, MIC, GC-MS,

\section{Background}

Antimicrobial resistance (AMR), a life-threatening and multifaceted global phenomenon, is a consequence of improper and/or overuse of antibiotics [1]. The Centre for Disease Control and Prevention (CDC) and the World Health Organization (WHO) report alarmingly increasing mortality rates as a result of infections from various MDR strains [2]. Some of the most lifethreatening MDR strains with severe human implications worldwide are Staphylococcus aureus MRSA, Acinetobacter baumannii, Pseudomonas aeruginosa, Escherichia coli, and Klebsiella pneumonia [3]. Globally, intensive care units (ICUs) are considered foci for the proliferation and promotion of persistent infection with MDR strains [4]. In Egypt, several studies have been conducted to trace the incidence and prevalence of AMR and its possible reasons, especially in ICUs $[5,6]$. Infection with Gram-negative MDR strains (e.g., Acinetobacter sp., Klebsiella sp., and Pseudomonas sp.) with a higher frequency than Gram-positive MDR strains was reported in the ICUs of Alexandria hospitals [4].

Increased health care expenditure for patients infected with MDR strains is one of the burdens imposed by AMR [7]. The Organization for Economic Cooperation and Development (OECD) reported that resistant microbes currently cause 700,000 deaths annually. If the current trends persist, the number of deaths is expected to rise to ten million by 2050, displacing cancer as one of the prime causes of mortality [8].

To combat AMR, innovative approaches must be adopted in the research for novel antimicrobial medicines. As the use of synthetic chemicals to combat MDR strains is highly restricted because of health and environmental considerations [9], turning to natural products is, then, an excellent alternate to control the prevalence of AMR. Centaurea spp L. are well-known for their bioactive secondary metabolites with antimicrobial potential against Gram-positive, Gram-negative, and MDR bacteria $[10-12]$. They have been reported to possess medicinally important EOs and large numbers of terpenoids with more than 3000 different structures [12]. The antimicrobial activity of many Centaurea spp. L. (e.g., $C$. pulcherrima, C. consanguinea, C. ptosomipappa, C. chamaerhaponticum, C. amanicola, C. sessilis, C. armena, and $C$. aladagensis) has already received researchers' attention [12]. Centaurea pumilio, Synonym $C$. aegialophila is a rare species that can be found scattered on sand dunes along the Egyptian Mediterranean coast [13]. Its dried root is frequently used as a fattening agent in traditional Egyptian medicine [14] and the indigenous people commonly use the peeled root to treat diabetes and bad breath. It has also been screened for efficacy against schistosomiasis and showed antioxidant activity [14]. C. pumilio is regarded as an endangered plant and has been included on the national Red List of the International Union for Conservation of Nature (IUCN) of threatened plants [13].

The objective of the present study was to extract EO and other active volatile constituents from the aerial part and the root of C. pumilio in order to assess the antimicrobial potential against 26 MDR strains collected from ICUs, 10 reference, and 16 clinical strains. To the best of the authors' knowledge, the current work represents the first study to separate and assess the antimicrobial potential of the active constituents in C. pumilio.

\section{Methods}

\section{Reagents and chemicals}

The chemicals and reagents used in this study were purchased from Sigma-Aldrich (St. Louis, MO, USA).

\section{Plant materials}

The plant was collected from its natural habitats on the Northern coast of Egypt during their flowering season (April and May 2018). It was identified as Centaurea pumilio L. by Prof. Dr. Salama El-Darer (Botany Department, Faculty of Science, Alexandria University, Egypt). A voucher specimen (CP019) was deposited in the herbarium of the Pharmacognosy Department. The fresh plant (Additional file 1) was air-dried, placed in a tightly sealed container, and stored in a cold, dark, dry place until the analyses were carried out. Permission to collect the plant samples was not required.

\section{Preparation of $C$. pumilio EO and extracts}

The EO was extracted in accordance with previously reported procedures [15]. The air-dried aerial part (400 g) was subjected to hydrodistillation using a Clevenger apparatus. The resultant pale yellow oil (Additional file 2) was stored at $-20^{\circ} \mathrm{C}$. Meanwhile, a solvent/solvent extraction method was employed to extract the active constituents from the aerial part and the root [16]. The 
powdered air-dried aerial part and root of C. pumilio $(700 \mathrm{~g})$ were extracted separately with $4 \mathrm{~L}$ methanol (70\%) until exhaustion. Both methanol extracts were filtered and concentrated under vacuum. The aqueous solutions were further extracted sequentially using four solvents with increasing polarities in the following order: petroleum ether, chloroform, ethyl acetate, and $n$-butanol. The organic phases of each extract from the aerial part and root, and the remaining aqueous extracts, were evaporated under reduced pressure (Fig. 1a, b).

\section{GC-MS analysis}

The gas chromatography-mass spectrometry (GC-MS) analyses of C. pumilio EO and chloroform aerial part extract were carried out using a GC-MS instrument with the following specifications: a TRACE GC Ultra Gas Chromatographs (Thermo Scientific Corp., USA) coupled with a Thermo mass spectrometer detector (ISQ Single Quadrupole Mass Spectrometer) [15, 16]. The experimental conditions of the GC-MS system were as follows: TR-5MS capillary standard non-polar column, dimension: 30Mts, ID: $0.25 \mathrm{~mm}$, and film thickness: $0.25 \mu \mathrm{m}$. The flow rate of the mobile phase (carrier gas: $\mathrm{He}$ ) was set at $1.0 \mathrm{ml} / \mathrm{min}$. In the gas chromatography phase, the temperature program (oven temperature) was set at $40^{\circ} \mathrm{C}$ and then raised to $250^{\circ} \mathrm{C}$ at $5^{\circ} \mathrm{C} / \mathrm{min}$ and the injection volume was $1 \mu \mathrm{L}$. The identification of the chemical constituents was de-

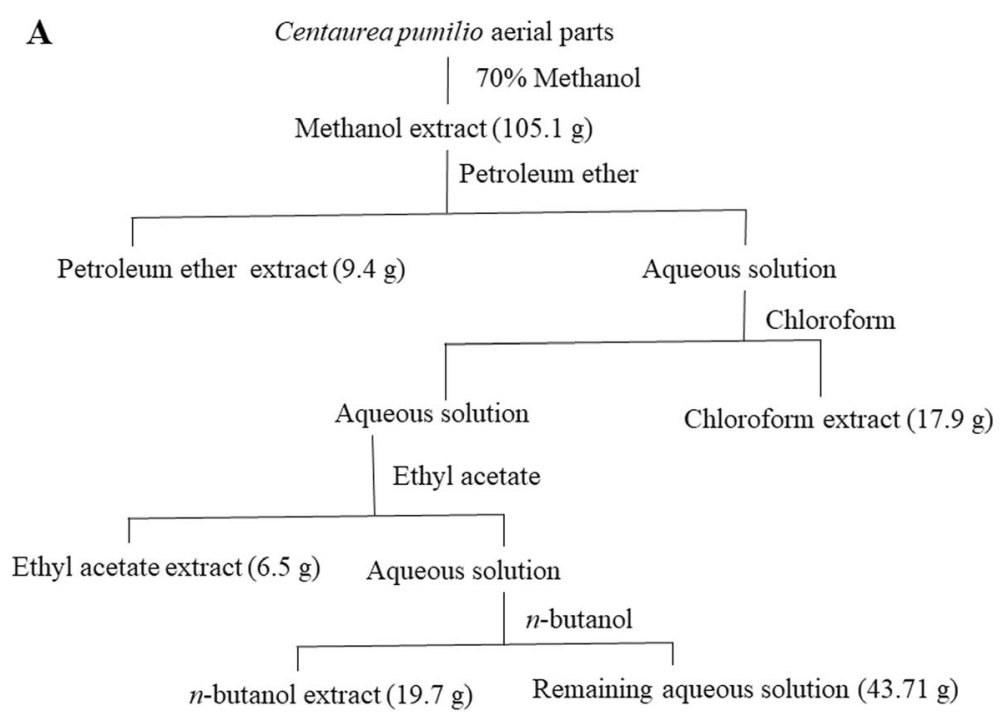

B

Centaurea pumilio roots $70 \%$ Methanol

Methanol extract $(97.5 \mathrm{~g})$

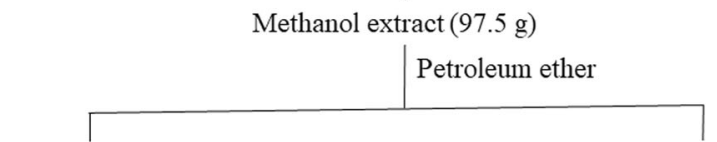

Petroleum ether extract $(8.7 \mathrm{~g})$

Aqueous solution

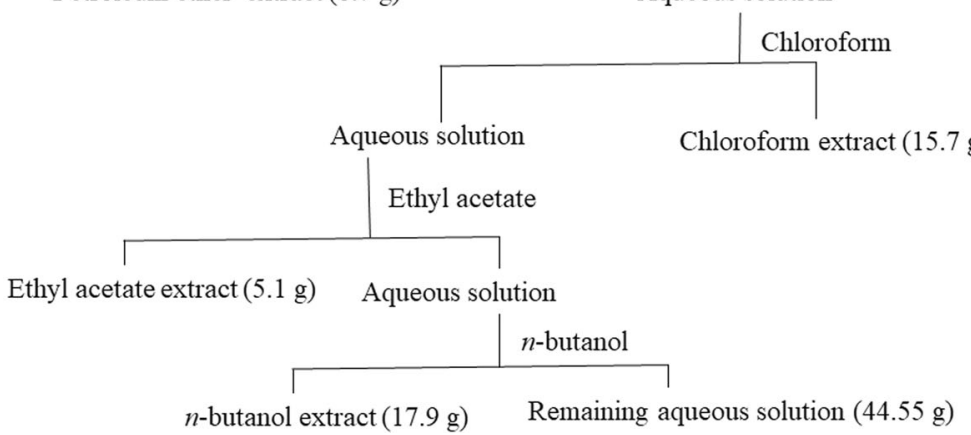

Fig. 1 Yield of bioactive compounds extracted from C. pumilio by solvent-solvent extraction method. a: Aerial part. b: Root 
convoluted using AMDIS software (Available at http:// www.amdis.net) and by their retention indices (RI determined with reference to homologous series of n-alkanes $\mathrm{C}_{9}-\mathrm{C}_{40}$, under identical experimental conditions), MS library search (NIST 08 MS Library Version $2.0 \mathrm{f}$ ), and WILEY MS 9th Edition (Thermo Fisher Scientific Austria) and by comparing with the MS literature data. The relative amounts of individual components were calculated based on the GC peak area (FID response) without using a correction factor.

\section{Standard commercial antibiotics}

Thirty-six commercial antibiotics (Sigma-Aldrich, St. Louis, MO, USA) were employed to assess the antibiotic resistance profile of the MDR strains. They were supplied as discs with known concentrations and are fully described in Additional file 3.

\section{Determination of antimicrobial activity Bacterial strains}

In the present study, ten reference strains: Acinetobacter baumannii ATCC 1797, E. coli ATCC 8739, Enterococcus faecalis ATCC 29212, Enterobacter aerogenes ATCC13048, Klebseilla pneumonia ATCC 700603, Pseudomonas aeruginosa ATCC 9027, Proteus mirabilis ATCC 14153, Salmonella enterica ATCC 14028, Staphylococcus aureus ATCC 6538, and Candida albicans ATCC 10231 were obtained from MIRCEN Faculty of Agriculture, Ain Shams University, Cairo, Egypt. Meanwhile, sixteen clinical strains were obtained from the Microbiology DepartmentFaculty of Medicine, Alexandria University, Egypt. Twenty-six multidrug resistant (MDR) strains were obtained from the ICUs Alexandria. The strains were identified using a three-step protocol: morphological identification, conventional biochemical tests and matrix-assisted laser desorption/ionization time of flight-mass spectrometry (MALDI-TOF-MS) (unpublished data). The sixteen clinical strains identified were Enterococcus faecalis, Staphylococcus aureus, Bacillus cereus (2 strains), Streptococcus mutans, Bacillus pumilus, Escherichia coli, Pseudomonas aeruginosa, Acinetobacter baumannii, Salmonella enterica serovar Typhi, Stenotrophomonas maltophilia, Proteus mirabilis, Klebseilla pneumonia (2 strains), Enterobacter $s p$. and Candida albicans. The twenty-six MDR strains were $S$. aureus MRSA (3 strains), A. baumannii (9 strains), $P$. aeruginosa (5 strains), E. coli (3 strains), K. variicola (one strain), and $K$. pneumonia (5 strains).

\section{Cultivation conditions}

The reference, clinical, and MDR strains were cultured on Müeller Hinton Broth (MHB, HiMedia, Mumbai, India) and Müeller Hinton Agar (MHA, HiMedia) at $37^{\circ} \mathrm{C}$ for $18 \mathrm{~h}$. However, C. albicans was cultivated on
Sabouraud Dextrose Broth (SDB, HiMedia) and Sabouraud Dextrose Agar (SDA, HiMedia) at $30^{\circ} \mathrm{C}$ for $18 \mathrm{~h}$.

\section{Disc diffusion assay}

The antibiotic resistance patterns of the MDR strains and the antimicrobial potential of the EO and extracts from C. pumilio against all the strains tested (i.e., reference, clinical, and MDR strains) were determined using the Kirby-Bauer disc diffusion technique $[17,18]$ as described by CLSI guidelines. An inoculum of 0.5 McFarland was used to inoculate the MHA and SDA agar plates. The EO or plant extract $(20 \mu \mathrm{L})$ was loaded onto the sterile filter paper discs at a concentration of 100 $\mathrm{mg} / \mathrm{mL}(2 \mathrm{mg} /$ disc $)$. Filter discs containing standard antimicrobial agents (ampicillin and fluconazole), EO, and extracts were employed in the pre-inoculated agar plates. The negative control plates were performed using dimethyl sulfoxide (DMSO). The diameters of the inhibition zones were measured and all the experiments were conducted in triplicate.

\section{Determination of minimal inhibitory concentration}

The minimum inhibitory concentrations (MIC) of the EO and extracts were determined with the broth microdilution method [18]. This was performed with 96-well microtiter plates using resazurin dye [19]. One hundred microliters $(100 \mu \mathrm{L})$ of cell suspensions $\left(5 \times 10^{5} \mathrm{CFU} /\right.$ $\mathrm{mL}$ ) were used to inoculate $50 \mu \mathrm{L}$ of $\mathrm{MHB}$ containing different concentrations $(15.62,31.25,62.5,125,250$, 500 , and $1000 \mu \mathrm{g} / \mathrm{mL}$ ) of the EO or extract. The inoculated microtitre plates were incubated at $37^{\circ} \mathrm{C}$ for $18 \mathrm{~h}$. The MIC values were the lowest concentrations of the EO and plant extracts that suppressed visible growth of each strain tested in the microtitre plate. Experiments were conducted in triplicate.

\section{Statistical analysis}

Data were statistically expressed in terms of means $(n=$ 3 ) \pm standard error (SE). Statistical analysis was run by the STATISTICA 10 of StatSoft, Inc. (2011) (Tulsa, Oklahoma, USA) [20]. Data variability was checked by one-way ANOVA at $P<0.05$ for plant extracts and a standard antibiotic against strains (indicated with capital letters (A-E) in the same row). Factorial ANOVA was checked at $P<0.05$ for each plant extract and the standard antibiotic to examine the factorial interaction between the reference and clinical strains and Grampositive bacteria and Gram-negative bacteria (indicated with the small letters (a-c) in the same column). The data variability of the chloroform extract from the aerial part was checked by one-way ANOVA at $P<0.05$ against the MDR strains; as indicated by the small letters $(\mathrm{a}-\mathrm{c})$ in the same column. 


\section{Results}

\section{Yield and chemical composition of EO and chloroform} extracts

The yields of the extracts from the aerial part and the root after performing a solvent/solvent extraction are depicted in Fig. 1a and b. The chloroform extract and hydrodistillation of the aerial part yielded $2.56 \%(\mathrm{w} / \mathrm{w})$ of brownish residue and $0.17 \%(\mathrm{v} / \mathrm{w})$ of pale yellow EO, respectively. A TRACE GC Ultra Gas Chromatographs (Thermo Scientific Corp., USA) was used to identify and quantify these components. Eighteen volatile compounds were identified in the EO (Table 1) with sesquiterpene hydrocarbons representing the major class, including $\beta$ caryophyllene (29.33\%) as the major volatile component, isogermacrene D (17.28\%), $\alpha$-cyperene (14.08\%), butanoic acid-2-methyl, 2-methyl butyl (11.16\%), caryophyllene oxide (10.49\%), $\alpha$-humulene (3.58\%), $\alpha$-copaene (2.14\%), $\gamma$-elemene (1.24\%), and T-muurolol (1.12\%).

The GC-MS analysis of the chloroform extract showed eighteen compounds (Table 2). It contained ten major active compounds including hydrocarbons [pentadecane (17.83\%), heptadecane (16.05\%), hexadecane (8.89\%), nonadecane $(7.88 \%)$, heneicosane $(7.30 \%)$, and heptacosane (6.08\%)], long-chain alkanes (tetradecane, 9.65\%), eicosane (7.10\%), 3-Oxo-10(14)-epoxyguai-11(13)-en-6, 12-olide (8.45\%), cis-13-eicosenoic acid (5.64\%), as well as other minor compounds. It is worth mentioning that this is, in fact, the first time a chemical analysis of the

Table 1 Chemical composition of essential oil (EO) of C. pumilio analyzed by GC-Mass spectrometry

\begin{tabular}{lllll}
\hline Peaks & Volatile compound & $\mathrm{Rl}$ & LRI & Content (\%) \\
\hline 1 & butanoic acid-2-methyl,2-methyl butyl & 1105 & 1106 & 11.16 \\
2 & Hexyl isovalerate & 1251 & 1253 & 0.99 \\
3 & 5-Methylhexyl 2-Methylbutanoate & 1298 & 1299 & 0.72 \\
4 & a-copaene & 1376 & 1375 & 2.14 \\
5 & a-Cyperene & 1398 & 1398 & 14.08 \\
6 & B-Caryophyllene & 1419 & 1419 & 29.33 \\
7 & a-Humulene & 1448 & 1449 & 3.58 \\
8 & Isogermacrene D & 1710 & 1708 & 17.28 \\
9 & Y-elemene & 1449 & 1449 & 1.24 \\
10 & a-Muurolene & 1492 & 1491 & 1.05 \\
11 & Y-Muurolene & 1472 & 1473 & 0.98 \\
12 & Caryophyllene oxide & 1571 & 1570 & 10.49 \\
13 & Caryophylladienol II & 1631 & 1632 & 0.57 \\
14 & T-Muurolol & 1628 & 1627 & 1.12 \\
15 & a-Valerenol & 1737 & 1736 & 0.64 \\
16 & Germacra-4 (15),5,10 (14)-trien-1 $\beta$-ol & 1687 & 1686 & 3.86 \\
17 & Trans-Valerenyl isovalerate & 2025 & 2024 & 0.43 \\
18 & Octacosane & 444 & 442 & 0.32 \\
\hline
\end{tabular}

$R /$ retention index, $L R$ l literature retention index
EO and the chloroform extract from the aerial part of $C$. pumilio has even been reported.

\section{Antibiogram of MDR strains}

The phenotypic profile of the 26 MDR strains against 36 commercial antibiotics is depicted in Additional file 3. There was a discrepancy in the antibiogram profile among the $26 \mathrm{MDR}$ strains belonging either to the same species or different genera in terms of the number and group of the antibiotics. The uppermost MDR strains exhibited resistance against 10-16 antibiotics.

\section{Antimicrobial activity of C. pumilio extracts and EO against reference and clinical strains}

The antimicrobial activities of $C$. pumilio EO and extracts against reference and clinical strains were assessed (Table 3). Using the factorial ANOVA at $P<0.05$, the inhibition zone diameters $(\mathrm{mm})$ of the chloroform, the ethyl acetate extracted from the aerial part, and the standard antibiotic showed significant data variability between the reference and clinical strains and between the Gram-positive and Gram-negative bacteria and their interactions (categorical factors). Statistical analysis proved that the highest significant data variability was observed between the Gram-positive and Gram-negative bacterial strains $(F=3.374, P<0.01)$ compared to those of the reference and clinical strains $(F=3.744, P<0.05)$ and their interactions $(F=2.176, P<0.05)$. No significant data variability was observed for the $70 \%$ methanol extract from the aerial part, the chloroform root extract, or the EO. The chloroform extract from the aerial part showed the highest inhibition zone diameters compared to the standard antibiotic, other extracts, and the EO. The inhibition zone diameters of the chloroform aerial part extract varied significantly as indicated by the different letters between the reference (mean $=27.11 \mathrm{~mm}$ ) and clinical strains $($ mean $=22.42 \mathrm{~mm})$. It also showed significant variance between the Gram-negative (mean = $20.40 \mathrm{~mm}$ ) and Gram-positive clinical bacterial strains (mean $=26.47 \mathrm{~mm})$. Furthermore, it showed the highest significant variability inferred by one-way ANOVA at $P<0.05$ among the other extracts and the standard antibiotic against each strain. The antibacterial activity of the ethyl acetate extract from the aerial part varied significantly between the reference $($ mean $=16.56 \mathrm{~mm}$ ) and clinical strains $($ mean $=15.41 \mathrm{~mm})$, and the Gramnegative (mean $=14.00 \mathrm{~mm}$ ) and Gram-positive clinical bacterial strains $($ mean $=18.58 \mathrm{~mm})$.

\section{Antimicrobial activity of C. pumilio extracts and EO against MDR strains}

Of the four extracts studied, only the chloroform aerial part extract showed potent antimicrobial activity against all the MDR strains tested (Table 4). Using the one-way 
Table 2 Chemical analysis of chloroform aerial part extract of C. pumilio analyzed by GC-Mass spectrometry

\begin{tabular}{|c|c|c|c|c|}
\hline Peaks & Volatile compound & $\begin{array}{l}\text { Content } \\
(\%)\end{array}$ & M.W. & $\mathrm{Rl}$ \\
\hline 1 & n-tetradecane & 9.65 & 198 & 1400 \\
\hline 2 & Carotene, 3,4-dihydro-1,1',2,2'-tetra hydro-1'-hydroxy-1-methoxy- & 0.58 & 584 & 1593 \\
\hline 3 & Pentadecane & 17.83 & 212 & 1502 \\
\hline 4 & Lochneridine (Curan-17-oic acid,2,16-didehydro-20-hydroxy-19-oxo,methyl ester & 0.67 & 398 & 2127 \\
\hline 5 & Hexadecane & 8.89 & 226 & 1601 \\
\hline 6 & Heptadecane & 16.05 & 240 & 1701 \\
\hline 7 & $\begin{array}{l}\text { 2a,4a-Epoxymethylphenanthrene-7-methanol,1,1-dimethyl-2-methoxy-8-(1,3-dithiin-2-ylidene) methyl-1,2,3,4,4a,4b,5,6,7, } \\
\text { 8,8a,9-dodecahydro-, acetate }\end{array}$ & 0.73 & 490 & 1933 \\
\hline 8 & Hydrazinecarboxamide & 0.45 & 75 & 829 \\
\hline 9 & 7,8-Epoxylanostan-11-ol, 3-acetoxy & 0.42 & 502 & 1734 \\
\hline 10 & Nonadecane & 7.88 & 268 & 1900 \\
\hline 11 & Octadecamethyl cyclononasiloxane & 0.63 & 666 & 1871 \\
\hline 12 & Eicosane & 7.10 & 282 & 2000 \\
\hline 13 & Hexadecamethyl Cyclooctasiloxane & 0.73 & 592 & 1700 \\
\hline 14 & Heneicosane & 7.30 & 296 & 2100 \\
\hline 15 & Octasiloxane, 1,1,3,3,5,5,7,7,9,9,11,11,13,13,15,15-hexadecamethyl- & 0.91 & 578 & 1759 \\
\hline 16 & Heptacosane & 6.08 & 380 & 2700 \\
\hline 17 & Cis-13-eicosenoic acid & 5.64 & 311 & 2365 \\
\hline 18 & 3-Oxo-10 (14)-epoxyguai-11 (13)-en-6,12-olide & 8.45 & 262 & 2010 \\
\hline
\end{tabular}

M.W. molecular weight, $R /$ retention index

ANOVA, the chloroform aerial part extract showed significant data variability among the MDR strains tested $(F=3.606, P<0.05)$, as indicated by the different letters (a-c). A discrepancy in the antimicrobial potential showed by the chloroform aerial part extract was noted among different strains of the same species. Among the nine MDR A. baumannii tested, inhibition zone diameters ranged from $11.33 \pm 0.33 \mathrm{~mm}$ to $23.33 \pm 0.33 \mathrm{~mm}$. Whilst, among the five MDR tested $K$. pneumonia, inhibition zone diameters ranged from $12.00 \pm 0.00 \mathrm{~mm}$ to $25.00 \pm 0.00 \mathrm{~mm}$. For the five MDR tested $P$. aeruginosa and the three MRSA strains tested, inhibition zone diameters ranged from $17.33 \pm 0.33 \mathrm{~mm}$ to $27.00 \pm 0.00$ $\mathrm{mm}$ and $20.00 \pm 0.00 \mathrm{~mm}$ to $28.00 \pm 0.00 \mathrm{~mm}$, respectively. Conversely, a negligible discrepancy in the range of the inhibition zone diameter was noted among the three MDR E. coli tested.

The growth of only nine out of the twenty-six tested MDR strains was inhibited by the EO (Table 4). At most, the highest inhibition zone diameter was $12.67 \pm 0.33$ $\mathrm{mm}$. The antimicrobial activity of the EO was not noticed against the nine MDR A. baumannii tested. EO inhibited the growth of only one out of the three MDR $E$. coli strains tested and only one out of five MDR $K$. pneumonia strains tested. In contrast, the growth of all the tested MDR P. aeruginosa strains was negatively influenced except for one strain. For the MRSA strains, only two out of three tested strains were adversely suppressed by EO.

\section{MIC of C. pumilio extracts and EO against reference and clinical strains}

At most, the highest antimicrobial activity among the four extracts was evidenced by the lowest MIC values observed (Table 5). With regard to the lowest MIC values, the antimicrobial potential of the extracts was in the following order: chloroform aerial part extract $>>>$ chloroform root extract $>>$ methanol aerial part extract $=$ ethyl acetate aerial part extract, when compared to MIC values of standard antibiotics. The chloroform aerial part extract exhibited an MIC value of $31.25 \mu \mathrm{g} /$ $\mathrm{mL}$ against the Gram-negative bacteria, Gram-positive bacteria, and C.albicans. However, the chloroform root extract showed an MIC value of $62.5 \mu \mathrm{g} / \mathrm{mL}$ against the Gram-negative bacteria and Gram-positive bacteria. At most, the chloroform aerial part extract demonstrated a twofold increase in the antibacterial and anticandidal activity as compared to the standard antibiotic against the clinical strains of $K$. pneumonia, $P$. aeruginosa, $P$. mirabilis, S. enetrica, and C. albicans. Moreover, a four-fold increase in the antibacterial activity of the chloroform aerial part extract was noted against $B$. pumilus. In contrast, the MIC values of $125-250 \mu \mathrm{g} / \mathrm{mL}$ of the methanol and ethyl acetate aerial part extracts were noticed 
Table 3 Inhibition zone diameters $(\mathrm{mm})$ of C. pumilio extracts and EO against reference and clinical strains

\begin{tabular}{|c|c|c|c|c|c|c|}
\hline \multirow[t]{2}{*}{ Stains } & \multicolumn{6}{|c|}{ Inhibition zone diameter (mm) } \\
\hline & $\begin{array}{l}70 \% \text { methanol aerial part } \\
\text { extract }\end{array}$ & $\begin{array}{l}\text { Chloroform aerial part } \\
\text { extract }\end{array}$ & $\begin{array}{l}\text { Ethyl acetate aerial part } \\
\text { extract }\end{array}$ & $\begin{array}{l}\text { Chloroform root } \\
\text { extract }\end{array}$ & EO & $\begin{array}{l}\text { Standard antimicrobial } \\
\text { agent }\end{array}$ \\
\hline \multicolumn{7}{|l|}{ Reference strains } \\
\hline A. baumannii ATCC 1797 & $10.00 \pm 0.58^{\mathrm{A}}$ & $25.00 \pm 0.58^{\mathrm{b} ; \mathrm{c}}$ & $16.00 \pm 0.00^{\mathrm{bc} ; \mathrm{B}}$ & ND & ND & $11.33 \pm 0.33^{\mathrm{a} ; \mathrm{A}}$ \\
\hline E. coli ATCC 8739 & $8.67 \pm 0.33^{A}$ & $29.33 \pm 0.33^{\mathrm{b}: \mathrm{D}}$ & $13.00 \pm 0.58^{\mathrm{bc} ; \mathrm{B}}$ & $10.00 \pm 0.00^{A}$ & $\begin{array}{l}9.33 \pm \\
0.33^{\mathrm{A}}\end{array}$ & $20.00 \pm 0.58^{\mathrm{a} ; \mathrm{c}}$ \\
\hline Ent. Faecalis ATCC 29212 & $11.33 \pm 0.33^{B}$ & $29.67 \pm-0.33^{\mathrm{b} ; \mathrm{D}}$ & $11.33 \pm 0.33^{\mathrm{bc} ; \mathrm{B}}$ & $8.33 \pm 0.33^{A}$ & $\begin{array}{l}8.33 \pm \\
0.33^{\mathrm{A}}\end{array}$ & $19.00 \pm 0.00^{\mathrm{a} ; \mathrm{c}}$ \\
\hline $\begin{array}{l}\text { Enterobacter aerogenes } \\
\text { ATCC13048 }\end{array}$ & $7.67 \pm 0.33^{A}$ & $17.67 \pm 0.33^{\mathrm{b} ; \mathrm{C}}$ & $9.67 \pm 0.33^{b c ; B}$ & ND & ND & ND \\
\hline $\begin{array}{l}\text { K. pneumonia ATCC } \\
700603\end{array}$ & $8.00 \pm 0.00^{A}$ & $22.67 \pm 0.33^{\mathrm{b} ; \mathrm{c}}$ & $11.67 \pm 0.33^{\mathrm{bc} ; \mathrm{B}}$ & $8.67 \pm 0.33^{A}$ & $\begin{array}{l}10.67 \pm \\
0.33^{\mathrm{B}}\end{array}$ & ND \\
\hline P. aeruginosa ATCC 9027 & $16.00 \pm 0.00^{C}$ & $29.67 \pm 0.33^{\mathrm{b}: \mathrm{E}}$ & $19.67 \pm 0.33^{b c ; D}$ & $11.00 \pm 0.00^{A}$ & $\begin{array}{l}14.67 \pm \\
0.33^{B}\end{array}$ & ND \\
\hline P. mirabilis ATCC 14153 & $8.67 \pm 0.33^{C}$ & $29.33 \pm 0.33^{\mathrm{b}: \mathrm{E}}$ & $15.67 \pm 0.33^{b c ; D}$ & $11.67 \pm 00^{A}$ & $\begin{array}{l}13.33 \pm \\
0.33^{\mathrm{B}}\end{array}$ & $12.00 \pm 0.00^{\mathrm{a} \mathrm{A} \mathrm{AB}}$ \\
\hline S. enterica ATCC 14028 & $7.33 \pm 0.33^{A}$ & $30.00 \pm 0.00^{\mathrm{b} ; \mathrm{D}}$ & $24.00 \pm 0.00^{b c ; c}$ & $7.67 \pm 0.33^{A}$ & $\begin{array}{l}12.33 \pm \\
0.33^{\mathrm{B}}\end{array}$ & ND \\
\hline S. aureus ATCC 6538 & $12.76 \pm 0.33^{\mathrm{B}}$ & $30.67 \pm 0.33^{\mathrm{ab}: \mathrm{E}}$ & $28.00 \pm 0.00^{c: D}$ & $14.33 \pm 0.33^{A}$ & $\begin{array}{l}13.33 \pm \\
0.33^{A}\end{array}$ & $25.00 \pm 0.00^{b c ; c}$ \\
\hline C. albicans ATCC 10231 & $8.33 \pm 0.33^{A}$ & $27.00 \pm 0.58^{\mathrm{abc} ; \mathrm{c}}$ & ND & $12.67 \pm 0.33^{B}$ & ND & $30.00 \pm 0.00^{\mathrm{c}: \mathrm{D}}$ \\
\hline \multicolumn{7}{|l|}{ Clinical strains } \\
\hline A. baumannii & $18.67 \pm 0.33^{A}$ & $10.67 \pm 0.33^{\mathrm{ac} ; \mathrm{B}}$ & $17.67 \pm 0.33^{\mathrm{ab} ; \mathrm{A}}$ & ND & ND & ND \\
\hline E. coli & $15.00 \pm 0.58^{\mathrm{B}}$ & $21.33 \pm 0.33^{\mathrm{ac} ; \mathrm{c}}$ & $19.33 \pm 0.33^{\mathrm{ab} ; \mathrm{c}}$ & $10.00 \pm 0.58^{A}$ & $\begin{array}{l}9.33 \pm \\
0.33^{\mathrm{A}}\end{array}$ & $14.33 \pm 0.03^{\mathrm{ab} ; \mathrm{B}}$ \\
\hline Ent. faecalis & $8.67 \pm 0.67^{B}$ & $20.67 \pm 0.33^{\mathrm{ac} ; \mathrm{D}}$ & $14.33 \pm 0.33^{\mathrm{ab} ; \mathrm{c}}$ & $11.67 \pm 0.33^{A}$ & $\begin{array}{l}10.00 \pm \\
0.58^{\mathrm{A}}\end{array}$ & $24.67 \pm 0.33^{\mathrm{ab} ; \mathrm{E}}$ \\
\hline Enterobacter sp. & $15.67 \pm 0.33^{A}$ & $16.67 \pm 0.33^{\mathrm{ac} ; \mathrm{A}}$ & $9.33 \pm 0.33^{\mathrm{ab} ; \mathrm{c}}$ & ND & ND & $8.00 \pm 0.00^{\mathrm{ab}: \mathrm{B}}$ \\
\hline K. pneumonia strain 1 & $8.33 \pm 0.33^{A}$ & $23.67 \pm 0.33^{\mathrm{ac} ; \mathrm{D}}$ & $7.33 \pm 0.33^{\mathrm{ab} ; \mathrm{A}}$ & $8.33 \pm 0.33^{A}$ & $\begin{array}{l}11.33 \pm \\
0.33^{\mathrm{B}}\end{array}$ & $19.00 \pm 0.00^{\mathrm{ab} ; \mathrm{c}}$ \\
\hline K. pneumonia strain2 & $15.00 \pm 0.58^{B}$ & $25.00 \pm 0.00^{a c ; D}$ & $18.33 \pm 0.33^{\mathrm{ab} ; \mathrm{c}}$ & $10.67 \pm 0.33^{A}$ & $\begin{array}{l}11.67 \pm \\
0.33^{\mathrm{A}}\end{array}$ & $15.33 \pm 0.33^{\mathrm{ab} ; \mathrm{B}}$ \\
\hline P. aeruginosa & $11.00 \pm 0.58^{A}$ & $24.00 \pm 0.00^{\mathrm{ac} ; \mathrm{c}}$ & $14.33 \pm 0.33^{\mathrm{ab} ; \mathrm{B}}$ & $11.67 \pm 0.33^{A}$ & $\begin{array}{l}13.67 \pm \\
0.33^{\mathrm{B}}\end{array}$ & $11.00 \pm 0.00^{\mathrm{ab} ; \mathrm{A}}$ \\
\hline P. mirabilis & $15.00 \pm 0.58^{\mathrm{A}}$ & $28.00 \pm 0.00^{\mathrm{ac} ; \mathrm{D}}$ & $17.00 \pm 0.58^{\mathrm{ab} ; \mathrm{A}}$ & $12.33 \pm 0.33^{C}$ & $\begin{array}{l}16.00 \pm \\
0.58^{\mathrm{A}}\end{array}$ & $9.00 \pm 0.00^{\mathrm{ab}: \mathrm{B}}$ \\
\hline S. enterica & $14.00 \pm 0.00^{A}$ & $25.00 \pm 0.00^{\mathrm{ac} ; \mathrm{E}}$ & $8.33 \pm 0.33^{\mathrm{ab} ; \mathrm{B}}$ & $15.33 \pm 0.33^{\mathrm{D}}$ & $\begin{array}{l}13.67 \pm \\
0.33^{\mathrm{A}}\end{array}$ & $11.33 \pm 0.33^{\mathrm{ab} ; \mathrm{c}}$ \\
\hline Steno. maltophilia & ND & $9.00 \pm 0.00^{a c ; A}$ & ND & $13.33 \pm 0.33^{B}$ & ND & $19.33 \pm 0.33^{\mathrm{ab} ; \mathrm{c}}$ \\
\hline B. cereus strain 1 & $8.67 \pm 0.67^{\mathrm{A}}$ & $30.00 \pm 0.00^{\mathrm{ab} ; \mathrm{D}}$ & $17.00 \pm 0.58^{\mathrm{bcc} c}$ & $10.67 \pm 0.33^{B}$ & $\begin{array}{l}10.33 \pm \\
0.33^{\mathrm{AB}}\end{array}$ & $16.33 \pm 0.33^{\mathrm{ab} ; \mathrm{c}}$ \\
\hline B. cerues strain2 & $14.00 \pm 0.58^{A}$ & $28.00 \pm 0.00^{\mathrm{ab} ; \mathrm{D}}$ & $17.33 \pm 0.33^{b c ; B}$ & $12.00 \pm 0.00^{c}$ & $\begin{array}{l}13.67 \pm \\
0.33^{\mathrm{A}}\end{array}$ & $16.33 \pm 0.33^{\mathrm{ab} ; \mathrm{B}}$ \\
\hline B. pumilus & $13.33 \pm 0.33^{A}$ & $30.33 \pm 0.33^{\mathrm{ab} ; \mathrm{D}}$ & $18.67 \pm 0.33^{b c ; c}$ & $12.33 \pm 0.33^{A}$ & $\begin{array}{l}12.67 \pm \\
0.33^{A}\end{array}$ & $7.00 \pm 0.00^{\mathrm{ab} ; \mathrm{B}}$ \\
\hline S. aureus & $9.67 \pm 0.88^{\mathrm{AB}}$ & $27.67 \pm 0.33^{\mathrm{ab} ; \mathrm{E}}$ & $21.33 \pm 0.33^{b c ; D}$ & $9.00 \pm 0.00^{A}$ & $\begin{array}{l}10.67 \pm \\
0.33^{B}\end{array}$ & $13.00 \pm 0.00^{\mathrm{ab} ; \mathrm{c}}$ \\
\hline Strep. mutans & ND & $16.33 \pm 0.33^{\mathrm{ab} ; \mathrm{B}}$ & ND & $10.33 \pm 0.33^{\mathrm{A}}$ & ND & ND \\
\hline C. albicans & $7.33 \pm 0.33^{A}$ & $12.00 \pm 0.00^{\mathrm{c} ; \mathrm{c}}$ & ND & $10.33 \pm 0.33^{B}$ & ND & $20.00 \pm 0.00^{\mathrm{abc} ; \mathrm{D}}$ \\
\hline
\end{tabular}

Different small letters $(\mathrm{a}-\mathrm{c})$ in the same column indicate significant data variability checked by factorial ANOVA at $P<0.05$. No letters indicate no significant variability

Different capital letters (A-E) in the same row indicate significant data variability checked by one-way ANOVA at $P<0.05$

$E O$ essential oil, $N D$ not detected 
Table 4 Inhibition zone diameters of chloroform aerial part $C$. pumilio extract and EO against MDR strains

\begin{tabular}{|c|c|c|}
\hline \multicolumn{3}{|c|}{ Inhibition zone diameter (mm) } \\
\hline MDR Strain & Chloroform aerial part extract & $\mathrm{EO}$ \\
\hline A. baumannii strain 1 & $11.67 \pm 0.33^{\mathrm{abc}}$ & - \\
\hline A. baumannii strain2 & $22.00 \pm 0.00^{\mathrm{abc}}$ & - \\
\hline A. baumannii strain3 & $20.00 \pm 0.00^{\mathrm{abc}}$ & - \\
\hline A. baumannii strain 4 & $16.00 \pm 0.00^{\mathrm{abc}}$ & - \\
\hline A. baumannii strain5 & $11.33 \pm 0.33^{\mathrm{abc}}$ & - \\
\hline A. baumannii strain6 & $21.67 \pm 0.33^{\mathrm{abc}}$ & - \\
\hline A. baumannii strain7 & $14.67 \pm 0.33^{\mathrm{abc}}$ & - \\
\hline A. baumannii strain8 & $20.00 \pm 0.00^{\mathrm{abc}}$ & - \\
\hline A. baumannii strain9 & $23.33 \pm 0.33^{\mathrm{abc}}$ & - \\
\hline E. coil strain 1 & $14.67 \pm 0.33^{\mathrm{ab}}$ & - \\
\hline E. coli strain2 & $17.67 \pm 0.33^{\mathrm{ab}}$ & $9.00 \pm 0.58$ \\
\hline E. coli strain 3 & $14.33 \pm 0.33^{\mathrm{ab}}$ & - \\
\hline K. pneumonia strain 1 & $16.00 \pm 0.00^{\mathrm{abc}}$ & - \\
\hline K. pneumonia strain2 & $12.00 \pm 0.00^{\mathrm{abc}}$ & - \\
\hline K. pneumonia strain3 & $12.67 \pm 0.33^{\mathrm{abc}}$ & - \\
\hline K. pneumonia strain4 & $25.00 \pm 0.00^{\mathrm{abc}}$ & - \\
\hline K. pneumonia strain5 & $24.00 \pm 0.00^{\mathrm{abc}}$ & $12.67 \pm 0.33$ \\
\hline K. variicola & $12.00 \pm 0.00^{a}$ & $10.33 \pm 0.33$ \\
\hline$P$. aeruginosa strain 1 & $20.00 \pm 0.00^{c}$ & - \\
\hline$P$. aeruginosa strain 2 & $25.00 \pm 0.00^{c}$ & $7.33 \pm 0.33$ \\
\hline$P$. aeruginosa strain 3 & $27.00 \pm 0.00^{c}$ & $7.33 \pm 0.33$ \\
\hline P. aeruginosa strain4 & $17.33 \pm 0.33^{c}$ & $9.33 \pm 0.33$ \\
\hline P. aeruginosa strain5 & $25.00 \pm 0.00^{c}$ & $11.33 \pm 0.33$ \\
\hline S. aureus MRSA strain1 & $21.00 \pm 0.00^{b c}$ & $4.00 \pm 0.00$ \\
\hline S. aureus MRSA strain2 & $20.00 \pm 0.00^{b c}$ & - \\
\hline S. aureus MRSA strain3 & $28.00 \pm 0.00^{b c}$ & $10.00 \pm 0.58$ \\
\hline
\end{tabular}

Different small letters (a-c) indicate significant data variability at $P<0.05$ checked by one-way ANOVA. No letters indicate no significant variability $M D R$ multidrug resistant, $E O$ essential oil

against Gram-negative bacteria and Gram-positive bacteria.

The common MIC values for the EO were $62.50 \mu \mathrm{g} /$ $\mathrm{mL}$ and $125 \mu \mathrm{g} / \mathrm{mL}$ for reference and clinical strains, respectively, against the Gram-negative bacteria and Gram-positive bacteria (Table 5).

\section{MIC of C. pumilio chloroform aerial part extract and EO against MDR strains}

The chloroform aerial part extract revealed its strong broad-spectrum antibacterial activity against the MDR strains with MIC values of $15.62 \mu \mathrm{g} / \mathrm{mL}$ (against $2 \mathrm{MDR}$ strains), $31.25 \mu \mathrm{g} / \mathrm{mL}$ (against $7 \mathrm{MDR}$ strains), $62.5 \mu \mathrm{g} /$ $\mathrm{mL}$ (against $14 \mathrm{MDR}$ strains), $125 \mu \mathrm{g} / \mathrm{mL}$ (against 2 MDR strains), and 250 (against one MDR strain). Moreover, these MIC values varied greatly among the strains belonging to the same species and among the strains of different species (Table 6). For instance, among the nine tested MDR A. baumannii, four MIC values of the $C$. pumilio chloroform aerial part extract were observed: $31.25,62.5,125$, and $250 \mu \mathrm{g} / \mathrm{mL}$. For the MIC values of the C. pumilio chloroform aerial part extract against MDR K. pneumonia, three values were noted: 15.62, 31.25 , and $62.5 \mu \mathrm{g} / \mathrm{mL}$, and these very same values were obtained against MDR $P$. aeruginosa as well. Conversely, only 62.5 and $125 \mu \mathrm{g} / \mathrm{mL}$ MIC values were noted against MRSA.

With regard to the EO MIC values, one fixed MIC value of $62.5 \mu \mathrm{g} / \mathrm{mL}$ was noted against MDR $P$. aeruginosa. However, two distal MIC values of 62.5 and $250 \mu \mathrm{g} / \mathrm{mL}$ were recorded against MRSA strains (Table 6). It showed antimicrobial activity against MDR E. coli and $K$. variicola with MIC values of 62.5 and $125 \mu \mathrm{g} / \mathrm{mL}$, respectively.

\section{Discussion}

In the ongoing search for natural antibiotics to treat human MDR infections, the current work focuses on looking for natural antimicrobial agents from $C$. pumilio extracts and EO.

Although the extracts and EOs of the genus Centaurea have been extensively studied and have showed remarkable antimicrobial activity against susceptible and MDR strains $[11,12,21]$, the antimicrobial activity of $C$. pumilio has not been well explored.

The EO from C. pumilio inhibited S. aureus (MIC, $31.52 \mu \mathrm{g} / \mathrm{mL}$ ), which is in accordance with $C$. carthamoides EO [12], and it also showed much higher antimicrobial activity against $S$. aureus, S. enetrica, and E. coli (with MIC values of $31.25,62.50$, and $125 \mu \mathrm{g} / \mathrm{mL}$, respectively), when compared to those of C. chamaer haponticum EO [12]. $\beta$-caryophyllene, a natural sesquiterpene, has been reported for its strong antimicrobial activity [22] and has previously been detected in the EOs of C. aladaghensis, C. amanicola, C. appendicigera, C. cheirolepidoides, C. deflexa, C. lanigera, and $C$. mucronifera [21]. It is worth mentioning that C. pumilio EO has the second-highest percentage of $\beta$ caryophyllene (29.33\%) after C. deflexa (33.9\%) [21]. The EO from C. pumilio demonstrated higher antimicrobial activity as indicated by the MIC values of 125,125 , and $62.5 \mu \mathrm{g} / \mathrm{mL}$ against B. cereus, $P$. aeruginosa, and $K$. pneumonia, respectively, when compared to those of $C$. solstitialis [15], C. appendicigera, and C. helenioides EOs [23]. C. pumilio EO also displayed more potent antibacterial activity than C. aladagensis [24], C. lycopifolia, and $C$. cheirolopha EOs [25]. Isogermacrene D, a monocyclic sesquiterpene hydrocarbon, has previously been reported in the EOs of C. antiochia, C. ptosimopappoides, $C$. babylonica, C. antitauri, C. balsamita, C. 
Table 5 Minimum inhibitory concentration (MIC) of C. pumilio extracts and EO against reference and clinical strains

\begin{tabular}{|c|c|c|c|c|c|c|}
\hline \multirow[t]{2}{*}{ Strains } & \multicolumn{6}{|l|}{$\mathrm{MIC}(\mu \mathrm{g} / \mathrm{mL})$} \\
\hline & $\begin{array}{l}70 \% \text { Methanol aerial part } \\
\text { extract }\end{array}$ & $\begin{array}{l}\text { Chloroform aerial part } \\
\text { extract }\end{array}$ & $\begin{array}{l}\text { Ethyl Acetate } \\
\text { aerial part }\end{array}$ & $\begin{array}{l}\text { Chloroform root } \\
\text { extract }\end{array}$ & $\mathrm{EO}$ & $\begin{array}{l}\text { Standard antimicrobial } \\
\text { agent }\end{array}$ \\
\hline \multicolumn{7}{|l|}{ Reference strains } \\
\hline $\begin{array}{l}\text { A. baumannii ATCC } \\
1797\end{array}$ & 125.0 & 62.50 & 125 & ND & ND & 62.50 \\
\hline E. coli ATCC 8739 & 125.0 & 31.25 & 125 & 250.0 & 62.50 & 7.80 \\
\hline $\begin{array}{l}\text { Ent. faecalis ATCC } \\
29212\end{array}$ & 125.0 & 62.50 & 250 & 62.5 & 62.50 & 0.97 \\
\hline $\begin{array}{l}\text { E. aerogenes ATCC } \\
13048\end{array}$ & 125.0 & 62.50 & 125 & ND & ND & ND \\
\hline $\begin{array}{l}\text { K. pneumonia ATCC } \\
700603\end{array}$ & 250.0 & 62.50 & 125 & 250.0 & 125.00 & ND \\
\hline $\begin{array}{l}\text { P. aeruginosa ATCC } \\
9027\end{array}$ & 250.0 & 62.50 & 125 & 125.0 & 62.50 & ND \\
\hline $\begin{array}{l}\text { Prot. mirabilis ATCC } \\
14153\end{array}$ & 250.0 & 62.50 & 250 & 125.0 & 62.50 & 15.62 \\
\hline $\begin{array}{l}\text { S. enterica ATCC } \\
14028\end{array}$ & 125.0 & 62.50 & 125 & 125.0 & 31.25 & ND \\
\hline S. aureus ATCC 6538 & 125.0 & 31.25 & 250 & 62.5 & 62.50 & 1.95 \\
\hline $\begin{array}{l}\text { C. albicans ATCC } \\
10231\end{array}$ & 62.5 & 62.50 & ND & 250.0 & ND & 1.95 \\
\hline \multicolumn{7}{|l|}{ Clinical strains } \\
\hline A. baumannii & 250.0 & 125.00 & 250 & ND & ND & ND \\
\hline E. coli & 250.0 & 62.50 & 250 & 125.0 & 125.00 & 3.90 \\
\hline Ent. faecalis & 250.0 & 31.25 & 125 & 125.0 & 125.00 & 7.81 \\
\hline Enterobacter sp. & 250.0 & 125.00 & 250 & ND & ND & 125.00 \\
\hline $\begin{array}{l}\text { K. pneumonia strain } \\
1\end{array}$ & 125.0 & 62.50 & 250 & 125.0 & 125.00 & 31.25 \\
\hline $\begin{array}{l}\text { K. pneumonia strain } \\
2\end{array}$ & 125.0 & 31.25 & 250 & 125.0 & 62.50 & 62.50 \\
\hline P. aeruginosa & 125.0 & 31.25 & 250 & 62.5 & 125.00 & 125.00 \\
\hline Prot. mirabilis & 125.0 & 31.25 & 125 & 62.5 & 125.00 & 62.50 \\
\hline S. enterica & 250.0 & 31.25 & 250 & 62.5 & 62.50 & 125.00 \\
\hline Steno. maltophilia & 125.0 & 125.00 & ND & 125.0 & ND & 125.00 \\
\hline B. cereus strain 1 & 125.0 & 62.50 & 125 & 125.0 & 125.00 & 7.81 \\
\hline B. cerues strain 2 & 250.0 & 62.50 & 125 & 125.0 & 125.00 & 31.25 \\
\hline B. pumilus & 125.0 & 31.25 & 250 & 62.5 .0 & 125.00 & 125.00 \\
\hline S. aureus & 62.5 & 62.50 & 125 & 125.0 & 31.25 & 31.25 \\
\hline Strep. mutans & ND & 62.50 & ND & 62.5 & ND & ND \\
\hline C. albicans & 125.0 & 31.25 & ND & 125.0 & ND & 62.50 \\
\hline
\end{tabular}

EO essential oil, $N D$ not detected

cheirolepidoides, and C. aladaghensis [21] and the EOs from C. helenioides [23], C. rupestris [18], C. solstitialis [15], C. baseri [26], C. cinerari, and C. napifolia [27] have been noted for their isogermacrene $\mathrm{D}$ content and antimicrobial activity that match with the present findings of C. pumilio EO.

The current study deals with the antimicrobial potential of four extracts; methanol, chloroform, and ethyl acetate aerial part extract and chloroform root extract. The methanol extract demonstrated high antibacterial activity against $S$. aureus and A. baumannii strains (MIC, $\quad 62.50 \mu \mathrm{g} / \mathrm{mL}$ and $250 \mu \mathrm{g} / \mathrm{mL}$, respectively), whereas in comparison, C. ragusina methanol extract shows less antibacterial activity [11]. Additionally, it exhibited the highest antimicrobial potential against $S$. aureus, B. cerues, and E. coli with MIC of $62.50,125$, and 
Table 6 Minimum inhibitory concentration (MIC) of C. pumilio chloroform extract and essential oil (EO) against 26 MDR strains

\begin{tabular}{|c|c|c|}
\hline \multirow[t]{2}{*}{ MDR strains } & \multicolumn{2}{|l|}{$\mathrm{MIC}(\mu \mathrm{g} / \mathrm{mL})$} \\
\hline & Chloroform aerial part extract & $\mathrm{EO}$ \\
\hline A. baumannii strain1 & 31.25 & - \\
\hline A. baumannii strain2 & 250.00 & - \\
\hline A. baumannii strain3 & 62.50 & - \\
\hline A. baumannii strain4 & 62.50 & - \\
\hline A. baumannii strain5 & 125.00 & - \\
\hline A. baumannii strain6 & 31.25 & - \\
\hline A. baumannii strain7 & 62.50 & - \\
\hline A. baumannii strain8 & 62.50 & - \\
\hline A. baumannii strain9 & 31.25 & - \\
\hline E. coli strain 1 & 31.25 & - \\
\hline E. coli strain2 & 62.50 & 62.50 \\
\hline E. coli strain3 & 62.50 & - \\
\hline K. pneumonia strain 1 & 15.62 & - \\
\hline K. pneumonia strain2 & 62.50 & - \\
\hline K. pneumonia strain3 & 62.50 & - \\
\hline K. pneumonia strain4 & 62.50 & - \\
\hline K. pneumonia strain5 & 31.25 & - \\
\hline K. variicola & 62.50 & 125.00 \\
\hline P. aeruginosa strain 1 & 62.50 & - \\
\hline P. aeruginosa strain2 & 62.50 & 62.50 \\
\hline P. aeruginosa strain3 & 15.62 & 62.50 \\
\hline P. aeruginosa strain4 & 31.25 & 62.50 \\
\hline P. aeruginosa strain 5 & 31.25 & 62.50 \\
\hline S. aureus MRSA strain 1 & 125.00 & 250.00 \\
\hline S. aureus MRSA strain2 & 62.50 & - \\
\hline S. aureus MRSA strain3 & 62.50 & 250.00 \\
\hline
\end{tabular}

MDR multidrug resistant

$250 \mu \mathrm{g} / \mathrm{mL}$, respectively, when compared to the same extract from twelve Centaurea spp. [28]. C. persica, C. polyclada, and $C$. consanguinea methanol extracts also demonstrated anticandidal activity with MIC of $125 \mu \mathrm{g} /$ $\mathrm{mL}$ [29].

Neither the C. pumilio methanol nor the ethyl acetate extract showed any activity against Strep. mutans, which is in agreement with C. austro-anatolica [17] and C. cariensis [30]. This discrepancy might be because of species differences. Unlike the C. cadmea methanol root extract [31] and $C$. montana root ethyl acetate and $n$-butanol extracts, C. pumilio chloroform root extract did show antimicrobial activity [32], and contrary to the C. montana root chloroform extract [32], the corresponding C. pumilio extract did suppress C. albicans growth (MIC, $125 \mu \mathrm{g} / \mathrm{mL}$ ).

Interestingly, the C. pumilio chloroform aerial part extract exhibited a twofold increase in the anticandidal activity to that of the standard antibiotic. This anticandidal activity is also seen in C. thessala and C. attica chloroform aerial part extracts [33], but not in the chloroform extracts of C. austro-anatolica, C. cariensis subsp. niveo-tomentosa, and C. ensiformis [17, 30, 34]. Strep. mutans and Steno. maltophilia were inhibited by chloroform extracts of both the root and aerial part of C. pumilio (MIC of 62.50 and $125 \mu \mathrm{g} / \mathrm{mL}$, respectively). Meanwhile, the C. pumilio chloroform aerial part extract exhibited higher antibacterial activity against MRSA (21, 20 , and $28 \mathrm{~mm}$ ) than that of C. austro-anatolica [17] and C. cariensis [30]. Previous studies demonstrated that the chloroform extracts from the aerial part of $C$. austro-anatolica and C. cariensis had antibacterial activity against MDR Steno. maltophilia strains $[17,30]$.

The C. pumilio EO inhibited the growth of Ent. faecalis (MIC, $125 \mu \mathrm{g} / \mathrm{mL}$ ) more than the $\mathrm{EO}$ from C. helenioides did [23] and MRSA (MIC, $250 \mu \mathrm{g} / \mathrm{mL}$ ) more than the C. baseri EO [26]. The antibacterial activity of the C. pumilio EO against MRSA may be attributed to its $15 \%$ isogermacrene D content [12]. The antimicrobial activity of the C. pumilio EO against the reference, clinical, and MDR strains might be attributed to its high content of sesquiterpenes [12]: $\beta$-caryophyllene (29.33\%), isogermacrene $\mathrm{D}(17.28 \%), \alpha$-cyperene (14.08\%), and caryophyllene oxide $(10.49 \%)$. The literature reviews revealed that EOs containing high percentages of $\beta$ caryophyllene augmented antibiotic potency against Gram-negative bacteria [35]. This would suggest that $C$. pumilio $\mathrm{EO}$ is a good candidate for new formulations that can contribute to reducing AMR [35]. The current study revealed for the first time the presence of butanoic acid, 2-methyl-, 2-methylbutyl ester which has been reported for its antimicrobial activity as it is the main component in Ammi visnaga L. EO [36]. Therefore, it might also contribute to the antimicrobial activity of the C. pumilio EO. So far, the findings of the current study concerning the antimicrobial activity of the C. pumilio EO against the MDR $P$. aeruginosa, E. coli, and $K$. variicola strains can be considered as the first report among the Centaurea genus. This would underpin the great potential the C. pumilio EO has in the fight against the MDR strains with global health implications the WHO and $\mathrm{CDC}$ annual statistical estimates have reported [2]. As a consequence, it represents an excellent natural alternative to the inefficient synthetic anti-MDR agents.

The GC-MS analysis of the C. pumilio chloroform aerial part extract reported hydrocarbons as the most abundant constituents and showed antibacterial activity against the clinical and MDR pathogens [37-41]. Pentadecane and heptadecane are the major hydrocarbons and these have been reported for their antimicrobial activity [39-41]. Tetradecane, hexadecane, nonadecane, and heneicosane were recorded as antimicrobial agents 
[41]. Eicosane, a long-chain fatty acid, has been reported for its antibacterial activity [41]. Pentadecane, tetradecane, hexadecane, nonadecane, heneicosane, eicosane, and heptacosane have previously been detected in $C$. napifolia, C. iconiensis, C. antiochia, C. aladaghensis, C. lanigera, C. iconiensis, and C. solstitialis, respectively $[15,21,27]$. The anticandidal activity of the C. pumilio chloroform aerial part extract might be accredited to 3oxo-10(14)-epoxyguai-11(13)-en-6,12-olide and curan17-oic acid,2,16-didehydro-20-hydroxy-19-oxo,methylester which have been described as antifungal agents [41, 42]. In addition, Cis-13-eicosenoic acid was detected in Camilla sinesis extract that was described for its antimicrobial activity against MRSA and MDR P. aeureginosa with MIC of $400 \mu \mathrm{g} / \mathrm{mL}$ and $800 \mu \mathrm{g} / \mathrm{mL}$, respectively [43]. Consequently, the significant antimicrobial activity of the C. pumilio chloroform aerial part extract against the MDR $P$. aeureginosa and MRSA strains (MIC of 62.5 and $15.62 \mu \mathrm{g} / \mathrm{mL}$, respectively) may be attributed to its content of cis-13-eicosenoic acid. The antimicrobial activities of the C. pumilio chloroform aerial part extract against the reference, clinical, and MDR pathogens are likely attributed to these bioactive compounds. The presence of these highly synergistic active compounds with high percentages in the chloroform aerial part extract may illustrate its potent antimicrobial activity against susceptible and MDR bacteria [44]. Noticeably, it is the aerial part of C. pumilio that contains more antimicrobial compounds in the EO, methanol, ethyl acetate, and chloroform extract compared to those in the root.

\section{Conclusions}

The current study is considered the first attempt to extract and assess the antimicrobial activity of the EO and extracts from C. pumilio not only against susceptible bacteria, but also MDR strains. This study does support the usage of $C$. pumilio as a medicinal plant as it is an extremely rich supplier of potent broad-spectrum antimicrobial bioactive compounds. The results of the research on the antimicrobial activity of $C$. pumilio showed that the extracts from the plant do exhibit strong activity, which is particularly promising given that antimicrobial resistance has become a major health issue worldwide. There is clear potential for C. pumilio EO and extracts to be exploited in the pharmaceutical industries and in the formulations of food additives for prophylaxis purposes. That said, further studies are mandatory to purify the chemical constituents of the antimicrobial fractions to better illustrate their mode of action. Moreover, the cytotoxicity levels of C. pumilio $\mathrm{EO}$ and extracts should also be studied further in vitro and in vivo to develop stable drugs for human/animal use.

\section{Supplementary information}

Supplementary information accompanies this paper at https://doi.org/10. 1186/s12906-020-2876-y.

Additional file 1: Morphology of the wild rare plant C. pumilio L..

Additional file 2: Extracted essential oil (EO) from the wild rare plant $C$. pumilio L..

Additional file 3: Table S1. Profile of antibiotic resistance of 26 MDR strains from ICUs in Alexandria hospitals.

\section{Abbreviations}

AMR: Antimicrobial resistance; CDC: Centre for disease control and prevention; DMSO: Dimethyl sulfoxide; EO: Essential oil; GC-MS: Gas chromatography-mass spectrometry; ICUs: Intensive care units;

IUCN: International union for conservation of nature; MALDI-TOF-MS: Matrixassisted laser desorption/ionization time of flight-mass spectrometry; MDR: Multidrug resistant; MIC: Minimum inhibitory concentration; OECD: Organization for economic cooperation and development

\section{Acknowledgments}

We are very grateful to Prof. Dr. Salama El-Darer, Faculty of Science, Botany Department, Alexandria University, Egypt for identifying the plant.

\section{Authors' contributions}

$\mathrm{HN}$ : carried out plant collection, laboratory work, writing the manuscript draft, and participated in the revised final form of the manuscript. AME: put the research idea, discussed laboratory data, wrote the manuscript draft, and revised the final form of the manuscript. AE: carried out all experiments of GC-MS analysis and their data discussion. RAR: put the design of all experiments of photochemistry, analyzed and discussed all data derived from extraction experiments. $\mathrm{AH}$ : participated in setting the experimental designs, analyzed all laboratory data, and revised the final form of the manuscript. MAD: participated in data discussion and revised the final form of the manuscript. All authors read and approved the final manuscript.

\section{Funding}

This research received no specific grant from any funding agency in the public, commercial, or not-for-profit sectors.

Availability of data and materials

The authors declare that all data are included in the manuscript without any restriction.

Ethics approval and consent to participate

Not applicable.

Consent for publication

Not applicable.

\section{Competing interests}

The authors declare that they have no competing interests.

\section{Author details}

'Department of Biotechnology, Institute of Graduate Studies and Research, Alexandria University, 163 Horreya Avenue, Chatbye, P.O.Box 832, Alexandria, Egypt. ${ }^{2}$ Pharmaceutical Bioproducts Research Department, Genetic Engineering \& Biotechnology Research Institute (GEBRI), City of Scientific Research and Technological Applications (SRTA-City), New Borg El-Arab City, Alexandria, Egypt. ${ }^{3}$ Medical Biotechnology Department, GEBRI, SRTA-City, New Borg El-Arab City, Alexandria, Egypt. ${ }^{4}$ Department of Pharmacognosy, Faculty of Pharmacy, Alexandria University, Alexandria, Egypt.

Received: 9 December 2019 Accepted: 28 February 2020

Published online: 12 March 2020

References

1. Prestinaci F, Pezzotti P, Pantosti A. Antimicrobial resistance: a global multifaceted phenomenon. Pathog Glob Health. 2015;109(7):309-18. https:// doi.org/10.1179/2047773215Y.0000000030. 
2. World Health Organization. Antimicrobial resistance global report on surveillance: 2014 summary. No. WHO/HSE/PED/AIP/2014.2: World Health Organization; 2014. https://apps.who.int/iris/bitstream/handle/10665/11264 7/WHO_HSE_PED_AIP_2014.2_eng.pdf. Accessed 24 Apr 2014.

3. Yu Z, Tang J, Khare T, Kumar V. The alarming antimicrobial resistance in ESKAPEE pathogens: can essential oils come to the rescue? Fitoterapia. 2020;104433. https://doi.org/10.1016/j.fitote.2019.104433.

4. El-Nawawy A, Ashraf GA, Antonios MA, Meheissen MA, El-Alfy MM. Incidence of multidrug-resistant organism among children admitted to pediatric intensive care unit in a developing country. Microb Drug Resist. 2018;24:1198-206. https://doi.org/10.1089/mdr.2017.0414.

5. Talaat M, El-Shokry M, El-Kholy J, Ismail G, Kotb S, Hafez S, et al. National surveillance of health care-associated infections in Egypt: developing a sustainable program in a resource-limited country. Am J Infect Control. 2016;44:1296-301. https://doi.org/10.1016/j.ajic.2016.04.212

6. Fathi I, Sameh O, Abu-Ollo M, Naguib A, Alaa-Eldin R, Ghoneim D, et al. Knowledge, attitudes, and beliefs regarding antimicrobial therapy and resistance among physicians in Alexandria University teaching hospitals and the associated prescription habits. Microb Drug Resist. 2015;23:71-8. https:// doi.org/10.1089/mdr.2015.0279.

7. Utt E, Wells $C$. The global response to the threat of antimicrobial resistance and the important role of vaccines. Pharm Policy Law. 2016;18:179-97. https://doi.org/10.3233/PPL-160442.

8. Ellen ME, Hughes F, Shach R, Shamian J. How nurses can contribute to combating antimicrobial resistance in practice, research and global policy. Int J Nurs Stud. 2017;71:A1-3. https://doi.org/10.1016/j.jinurstu.2017.02.023.

9. Swamy MK, Akhtar MS, Sinniah UR. Antimicrobial properties of plant essential oils against human pathogens and their mode of action: an updated review. Evid Based Complement Alternat Med. 2016;21:3012462. https://doi.org/10.1155/2016/3012462

10. Özçelik B, Gürbüz I, Karaoglu T, Yeşilada E. Antiviral and antimicrobial activities of three sesquiterpene lactones from Centaurea solstitialis L. ssp. solstitialis. Microbiol Res. 2009;164:545-52. https://doi.org/10.1016/j.micres. 2007.05.006.

11. Grienke U, Radić Brkanac S, Vujčić V, Urban E, Ivanković S, Stojković R, Rollinger JM, Kralj J, Brozovic A, Radić Stojković M. Biological activity of flavonoids and rare sesquiterpene lactones isolated from Centaurea ragusina L. Front Pharmacol. 2018;9:972. https://doi.org/10.3389/fphar.2018.00972.

12. Abad MJ, Bedoya LM, Bermejo P. Essential oils from the Asteraceae family active against multidrug-resistant bacteria. In: Rai M, Kon K, editors. Fighting Multidrug Resistance with Herbal Extracts, Essential Oils and Their Components. United States: Academic Press; 2013. p. 205-21.

13. Muminović S, Kavgić I, Šajna N. Persistence of Centaurea pumilio L., a rare sand dune species. Ecol Mediterr. 2014;40:19-26 https://dialnet.unirioja.es/ servlet/articulo?codigo $=5221922$.

14. Mostafa E, Fayed MA, Radwan RA, Bakr RO. Centaurea pumilio L. extract and nanoparticles: A candidate for healthy skin. Colloids Surf B: Biointerfaces. 2019;182:110350. https://doi.org/10.1016/j.colsurfb.2019.110350.

15. Carev I, Ruščić M, Skočibušić M, Maravić A, Siljak-Yakovlev S, Politeo O. Phytochemical and cytogenetic characterization of Centaurea solstitialis L. (Asteraceae) from Croatia. Chem Biodivers. 2017;14:1600213. https://doi.org/ 10.1002/cbdv.201600213.

16. Ahmad S, Ullah F, Zeb A, Ayaz M, Ullah F, Sadiq A. Evaluation of Rumex hastatus D. Don for cytotoxic potential against HeLa and NIH/3T3 cell lines: chemical characterization of chloroform fraction and identification of bioactive compounds. BMC Complement Altern Med. 2016;16(1):308. https://doi.org/10.1186/s12906-016-1302.

17. Ugur A, Sarac N, Ceylan O, Duru M. Chemical composition of endemic Centaurea austro-anatolica and studies of its antimicrobial activity against multi-resistant bacteria. Acta Pharma. 2009;59:463-72. https://doi.org/10. 2478/v10007-009-0036-5.

18. Carev I, Maravić A, Bektašević M, Ruščić M, Siljak-Yakovlev S, Politeo O. Centaurea rupestris L.: cytogenetics, essential oil chemistry and biological activity. Croat Chem Acta. 2018;91:1-8. https://doi.org/10.5562/cca3205.

19. Elshikh M, Ahmed S, Funston S, Dunlop P, McGaw M, Marchant R, et al. Resazurin-based 96-well plate microdilution method for the determination of minimum inhibitory concentration of biosurfactants. Biotechnol Lett. 2016:38:1015-9. https://doi.org/10.1007/s10529-016-2079-2.

20. StatSoft Inc: STATISTICA (data analysis software system), version 10. 2011 Available at www.statsoft.com.
21. Flamini G, Tebano M, Cioni PL, Bagci Y, Dural H, Ertugrul K, et al. A multivariate statistical approach to Centaurea classification using essential oil composition data of some species from Turkey. Plant Syst Evol. 2006;261: 217-28. https://doi.org/10.1007/s00606-006-0448-3.

22. Dahham S, Tabana Y, lqbal M, Ahamed M, Ezzat M, Majid A, et al. The anticancer, antioxidant and antimicrobial properties of the sesquiterpene $\beta$ caryophyllene from the essential oil of Aquilaria crassna. Molecules. 2015;20: 11808-29. https://doi.org/10.3390/molecules200711808.

23. Yaylı N, Yaşar A, Yaylı N, Albay C, Aşamaz Y, Coşkunçelebi K, et al. Chemical composition and antimicrobial activity of essential oils from Centaurea appendicigera and Centaurea helenioides. Pharm Biol. 2009;47:7-12. https:// doi.org/10.1080/13880200802397970.

24. Köse $Y B$, Işcan $G$, Demirci $B$, Başer KHC, Celik S. Antimicrobial activity of the essential oil of Centaurea aladagensis. Fitoterapia. 2007;78:253-4. https://doi. org/10.1016/j.fitote.2006.12.002.

25. Bülent Köse $Y$, Iscan $G$, Demirci B. Antimicrobial activity of the essential oils obtained from flowering aerial parts of Centaurea lycopifolia Boiss. et Kotschy and Centaurea cheirolopha (Fenzl) Wagenitz from Turkey. J Essent Oil Bear Plants. 2016;19:762-8. https://doi.org/10.1080/0972060X.2016. 1174080.

26. Köse YB, İşcan G, Göger F, Akalın G, Demirci B, Başer KH. Chemical composition and biological activity of Centaurea baseri: new species from Turkey. Chem Biodivers. 2016;13:1369-79. https://doi.org/10.1007/s00606006-0448-310.1002/cbdv.201600070.

27. Senatore F, Rigano D, De Fusco R, Bruno M. Volatile components of Centaurea cineraria L. subsp. umbrosa (Lacaita) Pign. And Centaurea napifolia L. (Asteraceae), two species growing wild in Sicily. Flavour Fragr J. 2003;18: 248-51. https://doi.org/10.1002/ffj.1179.

28. Tekeli Y, Zengin G, Aktumsek A, Sezgin M, Torlak E. Antibacterial activities of extracts from twelve Centaurea species from Turkey. Arch Biol Sci. 2011;63: 685-90. https://doi.org/10.2298/ABS1103685T.

29. Uysal I, Saglam H, Guven K. Antimicrobial and antioxidant activities of some species of Centaurea collected from Turkey. Asian J Chem. 2013;25:666-70. https://doi.org/10.14233/ajchem.2013.12125.

30. Ugur A, Sarac N, Ceylan O, Emin DM. Antimicrobial activity and chemical composition of endemic Centaurea cariensis subsp. niveo-tomentosa. Nat Prod Res. 2010;24:861-72. https://doi.org/10.1080/14786410903315127.

31. Köksal CK. Cytotoxic and antibacterial activities of Centaurea cadmea Boiss. Turk J Pharm Sci. 2014;11:101-6 http://cms.galenos.com.tr/Uploads/ Article_12370/101-106.pdf.

32. Ahmad N, Shinwari ZK, Hussain J, Ahmad I, Perveen R, Rehman S. Phytochemical screening and biological activities of different parts of Centaurea montana. Int J Plant Sci Ecol. 2015;1:237-40 http://files.aiscience. org/journal/article/pdf/70060137.pdf.

33. Skaltsa H, Lazari D, Panagouleas C, Georgiadou E, Garcia B, Sokovic M. Sesquiterpene lactones from Centaurea thessala and Centaurea attica. Antifungal activity. Phytochemistry. 2000;55:903-8. https://doi.org/10.1016/ S0031-9422(00)00254-5.

34. Ugur A, Duru ME, Ceylan O, Sarac N, Varol O, Kivrak I. Chemical composition, antimicrobial and antioxidant activities of Centaurea ensiformis hub-Mor. (Asteraceae), a species endemic to Mugla (Turkey). Nat Prod Res 2009;23:149-67. https://doi.org/10.1080/14786410801915770.

35. Aelenei P, Miron A, Trifan A, Bujor A, Gille E, Aprotosoaie AC. Essential oils and their components as modulators of antibiotic activity against gramnegative bacteria. Medicines. 2016;3:19. https://doi.org/10.3390/ medicines3030019.

36. Feirouz B, Salima KG. Antibacterial activity and chemical composition of Ammi visnaga $\mathrm{L}$. essential oil collected from Boumerdes (Algeria) during three periods of the plant growth. J Essent Oil Bear Plants. 2014;17:1317-28. https://doi.org/10.1080/0972060X.2014.912164.

37. Burt S. Essential oils: their antibacterial properties and potential applications in foods-a review. Int J Food Microbiol. 2004;94:223-53. https://doi.org/10. 1016/j.ijfoodmicro.2004.03.022.

38. Boussaada O, Ammar S, Saidana D, Chriaa J, Chraif I, Daami M, Helal AN, Mighri Z. Chemical composition and antimicrobial activity of volatile components from capitula and aerial parts of Rhaponticum acaule DC growing wild in Tunisia. Microbiol Res. 2008;163:87-95. https://doi.org/10. 1080/10412905.2009.9700142.

39. Rahbar N, Shafagha A, Salimi F. Antimicrobial activity and constituents of the hexane extracts from leaf and stem of Origanum vulgare L. sp. Viride 
(Boiss.) Hayek. Growing wild in Northwest Iran. J Med Plant Res. 2012;6: 2681-5. https://doi.org/10.5897/JMPR11.1768.

40. Girija S, Veeramuthu D, Pandi Suba K, Hariprasad G, Raghuraman R. Chromatographic characterization and GC-MS evaluation of the bioactive constituents with antimicrobial potential from the pigmented ink of Loligo duvauceli. Int Sch Res Notices. 2014:820745. https://doi.org/10.1155/2014/ 820745.

41. Begum IF, Mohankumar R, Jeevan M, Ramani K. GC-MS analysis of bio-active molecules derived from Paracoccus pantotrophus FMR19 and the antimicrobial activity against bacterial pathogens and MDROs. Indian J Microbiol. 2016;56:426-32. https://doi.org/10.1007/s12088-016-0609-1.

42. Mohammed GJ, Omran AM, Hussein HM. Antibacterial and phytochemical analysis of Piper nigrum using gas chromatography-mass Spectrum and Fourier-transform infrared spectroscopy. Int JPharmacognosy Phytochem Res. 2016;8(6):977-96.

43. Gupta D, Kumar M. Evaluation of in vitro antimicrobial potential and GC-MS analysis of Camellia sinensis and Terminalia arjuna. Biotechnology Reports. 2017;13:19-25. https://doi.org/10.1016/j.btre.2016.11.002.

44. Zekeya N, Chacha M, Shahada F, Kidukuli A. Analysis of phytochemical composition of Bersama abyssinica by gas chromatography-mass spectrometry. J Pharmacogn Phytochem. 2014;3:246-52 http://www. phytojournal.com/vol3lssue4/Issue_nov_2014/29.1.pdf.

\section{Publisher's Note}

Springer Nature remains neutral with regard to jurisdictional claims in published maps and institutional affiliations.

Ready to submit your research? Choose BMC and benefit from:

- fast, convenient online submission

- thorough peer review by experienced researchers in your field

- rapid publication on acceptance

- support for research data, including large and complex data types

- gold Open Access which fosters wider collaboration and increased citations

- maximum visibility for your research: over $100 \mathrm{M}$ website views per year

At BMC, research is always in progress.

Learn more biomedcentral.com/submissions 